Biochem Biophys Res Commun. 2014 July 25; 450(2): 1104-1109. doi:10.1016/j.bbrc.2014.06.120.

\title{
A inhibitor of $\mathrm{Na}^{+} / \mathrm{Ca}^{2+}$ exchange blocks activation of insect olfactory receptors
}

\author{
Y Bobkov ${ }^{1}$, E Corey ${ }^{1}$, and B Ache ${ }^{1,2}$ \\ ${ }^{1}$ Whitney Laboratory, Center for Smell and Taste, McKnight Brain Institute, Univ. of Florida, \\ Gainesville, FL 32610 \\ ${ }^{2}$ Depts. of Biology and Neuroscience, Univ. of Florida, Gainesville, FL 32610
}

\begin{abstract}
Earlier we showed that the $\mathrm{Na}^{+} / \mathrm{Ca}^{2+}$ exchanger inhibitor, KB-R7943, potently blocks the odorevoked activity of lobster olfactory receptor neurons. Here we extend that finding to recombinant mosquito olfactory receptors stably expressed in HEK cells. Using whole-cell and outside-out patch clamping and calcium imaging, we demonstrate that KB-R7943 blocks both the odorantgated current and the odorant-evoked calcium signal from two different OR complexes from the malaria vector mosquito, Anopheles gambiae, AgOr48 + AgOrco and AgOr65 + AgOrco. Both heteromeric and homomeric (Orco alone) OR complexes were susceptible to KB-R7943 blockade when activated by VUAA1, an agonist that targets the Orco channel subunit, suggesting the Orco subunit may be the target of the drug's action. KB-R7943 represents a valuable tool to further investigate the functional properties of arthropod olfactory receptors and raises the interesting specter that activation of these ionotropic receptors is directly or indirectly linked to a $\mathrm{Na}+/ \mathrm{Ca}^{2+}$ exchanger, thereby providing a template for drug design potentially allowing improved control of insect pests and disease vectors.
\end{abstract}

\section{Keywords}

Mosquito olfactory receptor; ionotropic receptor; sodium calcium exchanger; inhibition

\section{Introduction}

Unlike vertebrates which use $\mathrm{G}$ protein-coupled receptor-based chemosensory transduction, arthropods use ionotropic receptors, including olfactory receptors (Ors), gustatory receptors (GRs) and variant ionotropic glutamate receptors (IRs) [1-6]. ORs and GRs are both seven transmembrane odorant-gated ion channels, while IRs are predicted to be structurally similar to traditional ionotropic glutamate receptors with a bipartite ligand-binding domain

\footnotetext{
(C) 2014 Elsevier Inc. All rights reserved

Corresponding author: Yuriy V. Bobkov, The Whitney Laboratory for Marine Bioscience, University of Florida, 9505 Ocean Shore Blvd., St. Augustine, FL 32080 lab (904) 461-4035 fax (904) 461-4008 bobkov@ whitney.ufl.edu.

Publisher's Disclaimer: This is a PDF file of an unedited manuscript that has been accepted for publication. As a service to our customers we are providing this early version of the manuscript. The manuscript will undergo copyediting, typesetting, and review of the resulting proof before it is published in its final citable form. Please note that during the production process errors may be discovered which could affect the content, and all legal disclaimers that apply to the journal pertain.
} 
separated by an ion pore forming region [5]. Despite their overall structural differences, ORs and IRs both form heteromultimeric complexes composed of a broadly expressed coreceptor and one or more additional subunits that determine the odorant specificity $[1,2,7]$

In addition to sharing supramolecular organization principles, ORs and IRs share common pharmacology in that both chemoreceptor families are sensitive to ruthenium red, amiloride and/or amiloride derivatives (ADs) $[8,1,6,9,10]$. Common susceptibility to these pharmacological agents suggests structural similarity of functional elements of the receptor complexes, e.g., the channel pore structure, and/or functional interaction with one or more ubiquitously expressed receptor-associated proteins. Specifically, the reported sensitivity to ADs, especially to pyrazine derivatives of amiloride, and the relative insensitivity to amiloride itself (e.g. [11,12] see [13 and 14] for review) potentially implicates the involvement of a Na${ }^{+} / \mathrm{Ca}^{2+}$ exchanger in the activation of ORs and IRs. Further, we previously found that KB-R7943, a compound initially introduced as a $\mathrm{Na}^{+} / \mathrm{Ca}^{2+}$ exchange inhibitor $[15,16]$, potently blocks the odor-evoked activity of lobster olfactory receptor neurons [17] which express IRs [18,19]. Based on the common susceptibility of ORs and IRs to other compounds, we explored the possibility that KB-R7943 would also block the activation of insect ORs.

Here we demonstrate that KB-R7943 blocks both the odorant-gated current and the odorantevoked calcium signal from two different OR complexes from the malaria vector mosquito, Anopheles gambiae, AgOr48 + AgOrco and AgOr65 + AgOrco. Both heteromeric and homomeric (Orco alone) OR complexes were susceptible to KB-R7943 blockade when activated by VUAA1, an agonist that targets the Orco channel subunit [7], suggesting the Orco subunit may be the target of the drug's action. KB-R7943 represents a valuable tool to further investigate the functional properties of arthropod ORs and raises the interesting specter that activation of arthropod chemosensory receptors, both ORs and IRs, is directly or indirectly linked to a $\mathrm{Na}^{+} / \mathrm{Ca}^{2+}$ exchanger.

\section{Materials and Methods}

\section{Heterologous expression}

The generation and use of OR-expressing HEK293T cell lines have been previously described [20]. Cells were incubated with $0.3 \mu \mathrm{g} / \mathrm{mL}$ tetracycline for 16 hours before the assay to induce OR expression.

\section{Electrophysiology, calcium imaging and data analysis}

AgOR channel activity was investigated using patch clamp recording in different configurations. The whole-cell and channel unitary currents were measured with an 200B patch-clamp amplifier (Molecular Devices, Sunnyvale, CA, USA) and a digital interface (Digidata 1320A, Molecular Devices, Sunnyvale, CA, USA), lowpass filtered at $5 \mathrm{kHz}$, sampled at $2-20 \mathrm{kHz}$ and in most cases digitally filtered at 1-1.4 kHz. Analysis of the data was carried out using pCLAMP 10 software (Molecular Devices, Sunnyvale, CA, USA) and SigmaPlot 11 (Systat Software Inc., San Jose, CA, USA). Currents were studied at a holding potential of $-50--40 \mathrm{mV}$ unless otherwise specified. The polarity of the currents/voltages is 
presented relative to intracellular membrane surface. Patch pipettes were fabricated from borosilicate capillary glass (BF150-86-10, Sutter Instrument, CA, USA) using a FlamingBrown micropipette puller (P-87, Sutter Instrument, CA, USA). Bath solution change was performed using a rapid solution changer with a modified tube holder, RSC-200 (Bio-Logic - Science Instruments, Claix, France). Data were recorded uner continuous perfusion with the solution of interest. The following modification of the Hill equation was used to fit the experimental data for KB dependent channel inhibition, $\mathrm{I}=1-\mathrm{I}_{\max } *[\mathrm{~KB}]^{\mathrm{h}} /\left([\mathrm{KB}]_{1 / 2}{ }^{\mathrm{h}}+[\mathrm{KB}]^{\mathrm{h}}\right)$, where $\mathrm{I}$ are the normalized current values, $[\mathrm{KB}]$ is the antagonist concentration, $[\mathrm{KB}]_{1 / 2}$ is the half-effective concentration, and $\mathrm{h}$ is the cooperativity coefficient. Whole-cell currentvoltage characteristics were generated using series of $15-\mathrm{ms}$ step at $-100 \mathrm{mV}$ followed by a 150 -ms voltage ramp (linear change in voltage $\sim 0.67 \mathrm{mV} / \mathrm{ms}$ ) from $-100 \mathrm{mV}$ to $+100 \mathrm{mV}$ were applied from a holding potential of $-50--40 \mathrm{mV}$. The interval between sweep starts was $1 \mathrm{~s}$. The data are presented as the mean $\pm \mathrm{SE}$ of $\mathrm{n}$ observations. All recordings were performed at room temperature $\left(\sim 20-21^{\circ} \mathrm{C}\right)$.

\section{Solutions and chemicals}

The standard extracellular $\mathrm{NaCl} 140 \mathrm{mM}$ solution contained (mM): $140 \mathrm{NaCl} ; 1-2 \mathrm{CaCl}_{2} ; 0-1$ $\mathrm{MgCl}_{2} ; 5 \mathrm{KCl} ; 10$ Hepes. The standard intracellular Na140mM low calcium solution contained (mM): $140 \mathrm{NaCl}$; 1-2 EGTA; 10 Hepes. Odorants, $\delta$-decalactone and Eugenol were purchased from Sigma (SAFC 30396PH) and Aldrich (05405JH) and prepared right before experiments as stock solutions $500 \mathrm{mM}$ in dimethylsulphoxide (DMSO) prior their dilution to different working concentrations. KB-R7943 (Carbamimidothioic acid, 2-[4-[(4nitrophenyl)methoxy]phenyl]ethyl ester, methanesulfonate (1:1); CAS Registry Number: 182004-65-5, SciFinder, Fig.1) was obtained from Tocris, Inc. Drug was dissolved in DMSO to give $100-200 \mathrm{mM}$ stock solutions. The $\mathrm{pH}$ of solutions was adjusted with $\mathrm{NaOH}$ or Trizma base (Sigma-Aldrich, St. Louis, MO, USA) to 7.3-7.4. VUAA1 (Acetamide, N-(4ethylphenyl)-2-[[4-ethyl-5-(3-pyridinyl)-4H-1,2,4-triazol-3-yl]thio]; CAS Registry Number: 525582-84-7, SciFinder) was provided by Dr. Zwiebel laboratory. All inorganic salts were purchased from Fisher Scientific (Pittsburgh, PA, USA). All organic compounds were obtained from Sigma-Aldrich.

\section{Results and Discussion}

All AgOR48+AgOrco-expressing HEK293T cells responded to the cognate odorant $\delta$ decalactone by generating a graded inward current to the maximum stimulus intensity (100 $\mu \mathrm{M})$ from -34 to $-1,721 \mathrm{pA}$, with a mean amplitude of $-413.5 \pm 29.5 \mathrm{pA}$ ( $\mathrm{n}=73$, Fig. 2A). Similarly, all AgOR65+AgOrco-expressing cells responded to the cognate odorant eugenol $(100 \mu \mathrm{M})$ by generating an inward current from -19 to $-934 \mathrm{pA}$, with a mean amplitude of $-212 \pm 29 \mathrm{pA}$ across 47 cells tested (Figure 2B). In both instances the appropriate noncognate odorants, eugenol and $\delta$-decalactone, failed to evoke inward currents, suggesting that activation of respective OR complexes by their cognate ordorant was highly specific and providing a control for non-specific activation of the cells by the odorants, the vehicle, and/or the method of stimulus application. In some cases, we used a mixture of eugenol $(100 \mu \mathrm{M})$ and $\delta$-decalactone $(100 \mu \mathrm{M})$ to stimulate the cells. While there is evidence of multimodal functioning (ionotropic and metabotropic modes) for at least some ORs 
[2,21-24], the rapid kinetics and stability of the responses in the whole cell recording mode is consistent with the ionotropic nature of the receptors proposed in the seminal studies [1,2] and later confirmed for a variety of ORs from different insect species (e.g., [7,25,26]).

We tested for AgOR/Orco sensitivity to the $\mathrm{Na}^{+} / \mathrm{Ca}^{2+}$ exchange inhibitor KB-R7943 using the following experimental paradigm. In whole-cell voltage clamp mode, at a holding potential of -40 to $-50 \mathrm{mV}, \mathrm{AgOR} / \mathrm{Orco}$ mediated currents were initially activated by the respective odorant at a saturating concentration $(100 \mu \mathrm{M})$. The drug was applied after the odorant-evoked currents reached a steady state level. KB-R7943 suppressed these currents in concentration-dependent manner (Fig.2A,B). The KB-R7943 effects were partially irreversible with the degree of recovery depending on the concentration and exposure time to KB-R7943 (Fig.2A inset, see also Fig.3 and 4). The effects were strongly voltage dependent and were more pronounced in the positive voltage range (Fig.2A,B). In some cases, high KB-R7943 concentrations augmented the inward currents (Fig.2A,B). While interesting, the nature of these currents is difficult to interpret in terms of the standard/ typical channel-blocker interaction. It should be noted however that KB-R7943 had little, if any, effect on either whole-cell currents of the cells expressing ORs in the absence of the respective ligands $(n=4 / 5)$ or on currents of untransfected HEK293T cells $(n=8)$. Overall the parameters of inhibition calculated from the KB-R7943 concentration dependences generated at $\sim+100 \mathrm{mV}$ were (inhibition constant, $\mathrm{IC}_{50}$; Hill coefficient, h; number of trials, n): for the AgOR48/AgOrco complex $(18 \pm 1.2,1.2 \pm 0.7, \mathrm{n}=6)$; for the AgOR65/AgOrco complex (14.1 $\pm 7.5,1.2 \pm 0.8, n=3-6)$ (Fig.2A,B). These results demonstrate that KB-R7943 is a potent inhibitor of insect ORs.

VUAA1 is a compound initially identified in a broad scale high throughput screening [7] to act as an agonist targeting the Orco subunit. We next tested whether KB-R7943 could block currents evoked by VUAA1 in a manner similar to which it blocks odorant-induced currents. As in the case of the cognate ligands, VUAA1 $(100 \mu \mathrm{M})$ evoked currents were blocked by a

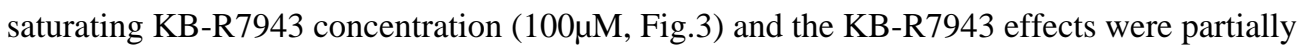
irreversible (Fig.3B, middle).

We also tested the effects of KB-R7943 on VUAA1-evoked AgOR/Orco channel activity using outside-out membrane patch recordings. KB-R7943 applied to extracellular side of membrane patch reversibly inhibited VUAA1 activated channel currents (Fig. 3E,F, right panels). In some cases, the membrane patch current level recorded in the presence of $100 \mu \mathrm{M}$ KB-R7943 was lower than the current noise in control conditions (before agonist application), perhaps suggesting some basal activity of AgORs. The channels demonstrated very brief gating parameters, opening and shutting events, making it practically impossible to carry out a detailed analysis of the gating behavior at the single channel level. While the outside out patch clamp recordings of single channel currents suggest that there is likely a direct interaction between KB-R7943 and AgORs, they provide little insight about the molecular target/mechanisms of the KB-R7943 effects. For example, it is still unclear whether inhibition is caused by an increased closed time of the channel (decrease in open channel probability) or by an open state block. Different approaches will be needed to address these questions in subsequent research. 
When expressed in the absence of a ligand-specific subunit, AgOrco subunits form functional homomeric channels that can be activated by VUAA1 and VUAA1 related compounds [7; 27]. We tested whether KB-R7943 was capable of blocking VUAA1-evoked currents in the cells expressing exclusively AgOrco and once again found that it could, with the effects of the blocker were only partially reversible and appeared to be voltage independent (Fig.4A). The parameters of inhibition were estimated to be [KB-R7943 $]_{1 / 2}$ $\sim 5.4 \mu \mathrm{M}, \mathrm{h} \sim 1.6, \mathrm{n}=3-7$ (Fig.4A, right panel). Since KB-R7943 has an effect independent of expression of the ligand-specific subunits, these results suggest that the Orco subunit or an associated protein endogenous to the HEK293T cells may be the target of the drug's action. Interestingly, the effects of KB-R794 on VUAA1 activated currents recorded from cells expressing AgOr48 + AgOrco or AgOrco alone were significantly less voltage dependent in comparison to cells expressing AgOr65+AgOrco (compare Fig.3B, Fig4A and Fig.3A). While speculative in the context of the current report these differences could be explained by variations in the biophysical and pharmacological characteristics of the receptor channel complexes predetermined by interaction of particular ligand-specific subunits with Orco [28-30].

Given that the blocking efficiency of KB-R7943 on currents generated by the cells expressing heteromeric AgOR/Orco complexes and activated by their cognate ligands is considerably voltage dependent, we next used calcium imaging to determine if KB-R7943 could be effective in "intact" (uncontrolled) voltage conditions. As in the electrophysiological experiments, KB-R7943 application suppressed calcium influx evoked by both the cognate ligands $\delta$-decalactone $(1-50 \mu \mathrm{M})$ and eugenol $(1-50 \mu \mathrm{M})$ as well as that

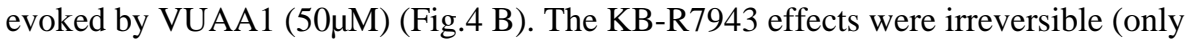
partially reversible after $\sim 20-30$ min washout), which made it impractical to determine the concentration dependence of the blockade. Under these experimental conditions, KB-R7943

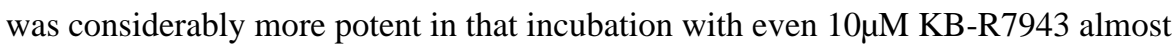
completely blocked the calcium responses. However, it is important to note that we cannot exclude the possibility that the compound can accumulate within cells or the cell membrane fraction ( $\log \mathrm{P} 2.87$, estimated using Advanced Chemistry Development (ACD/Labs) Software V11.02), thereby shifting the apparent inhibition constant. The different calcium response kinetics (calcium signal decay time is noticeably slower for AgOr48+AgOrco, Fig. 4B) are likely due to the differences in extracellular divalent cation concentrations used in the experiments. Overall despite the different experimental approach and experimental conditions, KB-R7943 was able to effectively disrupt both odorant and VUAA1 evoked calcium signals, consistent with data obtained in electrophysiological experiments.

The shared sensitivity of HEK293T cells expressing insect ORs and lobster ORNs expressing IRs to the pharmacological blockers including KB-R7943 [9,10,31,17] provides further support for that idea that these structurally different types of arthropod ionotropic chemosensory receptors are functionally similar. It also raises the specter of a novel functional mechanism - co-assembly of olfactory receptors with a ubiquitously expressed, conserved ion transporter. This idea gains support from the recent finding that ion channels and ion exchangers can form integral supra-molecular complexes with reciprocal pharmacology [32-37] and provides a new target for compounds designed to improve control of insect pests and disease vectors. Towards that end, we hope that our findings will 
stimulate a larger scale pharmacological and molecular analysis to identify and functionally characterize potential OR/IR-ion transporter/exchanger interactions.

\section{Acknowledgments}

This work was supported by National Institute on Deafness and Other Communication Disorders (DC001655). We thank Dr. Larry Zwiebel for generously sharing HEK cell lines expressing the mosquito OR complexes and VUAA1.

\section{Reference List}

[1]. Sato K, Pellegrino M, Nakagawa T, Nakagawa T, Vosshall LB, Touhara K. Insect olfactory receptors are heteromeric ligand-gated ion channels. Nature. 2008; 452:1002-10U9. [PubMed: 18408712]

[2]. Wicher D, Schafer R, Bauernfeind R, Stensmyr MC, Heller R, Heinemann SH, Hansson BS. Drosophila odorant receptors are both ligand-gated and cyclic-nucleotide-activated cation channels. Nature. 2008; 452:1007-1U10. [PubMed: 18408711]

[3]. Sato K, Tanaka K, Touhara K. Sugar-regulated cation channel formed by an insect gustatory receptor. Proceedings of the National Academy of Sciences of the United States of America. 2011; 108:11680-11685. [PubMed: 21709218]

[4]. Freeman EG, Wisotsky Z, Dahanukar A. Detection of sweet tastants by a conserved group of insect gustatory receptors. Proceedings of the National Academy of Sciences of the United States of America. 2014; 111:1598-1603. [PubMed: 24474785]

[5]. Benton R, Vannice KS, Gomez-Diaz C, Vosshall LB. Variant Ionotropic Glutamate Receptors as Chemosensory Receptors in Drosophila. Cell. 2009; 136:149-162. [PubMed: 19135896]

[6]. Abuin L, Bargeton B, Ulbrich MH, Isacoff EY, Kellenberger S, Benton R. Functional Architecture of Olfactory Ionotropic Glutamate Receptors. Neuron. 2011; 69:44-60. [PubMed: 21220098]

[7]. Jones PL, Pask GM, Rinker DC, Zwiebel LJ. Functional agonism of insect odorant receptor ion channels. Proceedings of the National Academy of Sciences of the United States of America. 2011; 108:8821-8825. [PubMed: 21555561]

[8]. Nakagawa T, Sakurai T, Nishioka T, Touhara K. Insect sex-pheromone signals mediated by specific combinations of olfactory receptors. Science. 2005; 307:1638-1642. [PubMed: 15692016]

[9]. Pask GM, Bobkov YV, Corey EA, Ache BW, Zwiebel LJ. Blockade of Insect Odorant Receptor Currents by Amiloride Derivatives. Chemical Senses. 2013; 38:221-229. [PubMed: 23292750]

[10]. Roellecke K, Werner M, Ziemba PM, Neuhaus EM, Hatt H, Gisselmann G. Amiloride Derivatives Are Effective Blockers of Insect Odorant Receptors. Chemical Senses. 2013; 38:231-236. [PubMed: 23329732]

[11]. Kleyman TR, Cragoe EJ. Amiloride and Its Analogs As Tools in the Study of Ion-Transport. Journal of Membrane Biology. 1988; 105:1-21. [PubMed: 2852254]

[12]. Rogister F, Laeckmann D, Plasman PO, Van Eylen F, Ghyoot M, Maggetto C, Liegeois JF, Geczy J, Herchuelz A, Delarge J, Masereel B. Novel inhibitors of the sodium-calcium exchanger: benzene ring analogues of N-guanidino substituted amiloride derivatives. European Journal of Medicinal Chemistry. 2001; 36:597-614. [PubMed: 11600230]

[13]. Blaustein MP, Lederer WJ. Sodium calcium exchange: Its physiological implications. Physiological Reviews. 1999; 79:763-854. [PubMed: 10390518]

[14]. Ji HL, Zhao RZ, Chen ZX, Shetty S, Idell S, Matalon S. delta ENaC: a novel divergent amiloride-inhibitable sodium channel. American Journal of Physiology-Lung Cellular and Molecular Physiology. 2012; 303:L1013-L1026. [PubMed: 22983350]

[15]. Iwamoto T, Watano T, Shigekawa M. A novel isothiourea derivative selectively inhibits the reverse mode of $\mathrm{Na}^{+} / \mathrm{Ca}^{2+}$ exchange in cells expressing NCX1. Journal of Biological Chemistry. 1996; 271:22391-22397. [PubMed: 8798401] 
[16]. Watano T, Kimura J, Morita T, Nakanishi H. A novel antagonist, No 7943, of the $\mathrm{Na}^{+} / \mathrm{Ca}^{2+}$ exchange current in guinea-pig cardiac ventricular cells. British Journal of Pharmacology. 1996; 119:555-563. [PubMed: 8894178]

[17]. Pezier A, Bobkov Y, Ache B. The $\mathrm{Na}^{+} / \mathrm{Ca}^{2+}$ Exchanger Inhibitor, KB-R7943, Blocks a Nonselective Cation Channel Implicated in Chemosensory Transduction. Journal of Neurophysiology. 2009; 101:1151-1159. V. [PubMed: 19118110]

[18]. Hollins B, Hardin D, Gimelbrant AA, Mcclintock TS. Olfactory-enriched transcripts are cellspecific markers in the lobster olfactory organ. Journal of Comparative Neurology. 2003; 455:125-138. [PubMed: 12455001]

[19]. Corey EA, Bobkov Y, Ukhanov K, Ache BW. Ionotropic Crustacean Olfactory Receptors. Plos One. 2013; 8

[20]. Bohbot JD, Jones PL, Wang G, Pitts R, Pask GM, Zwiebel LJ. Conservation of Indole Responsive Odorant Receptors in Mosquitoes Reveals an Ancient Olfactory Trait. Chemical Senses. 2011; 36:149-160. [PubMed: 20956733]

[21]. Kain P, Chakraborty TS, Sundaram S, Siddiqi O, Rodrigues V, Hasan G. Reduced odor responses from antennal neurons of G(q)alpha, phospholipase C beta, and rdgA mutants in Drosophila support a role for a phospholipid intermediate in insect olfactory transduction. Journal of Neuroscience. 2008; 28:4745-4755. [PubMed: 18448651]

[22]. Deng YD, Zhang WY, Farhat K, Oberland S, Gisselmann G, Neuhaus EM. The Stimulatory G alpha(s) Protein Is Involved in Olfactory Signal Transduction in Drosophila. Plos One. 2011; 6

[23]. Nolte A, Funk NW, Mukunda L, Gawalek P, Werckenthin A, Hansson BS, Wicher D, Stengl M. In situ Tip-Recordings Found No Evidence for an Orco-Based Ionotropic Mechanism of Pheromone-Transduction in Manduca sexta. Plos One. 2013; 8

[24]. Ignatious Raja JS, Katnayeva N, Katanaev VL, Galizia CG. Role of Go/i subgroup of G proteins in olfactory signaling of Drosophila melanogaster. European Journal of Neuroscience. 2014; 39:1245-1255. [PubMed: 24443946]

[25]. Mitchell RF, Hughes DT, Luetje CW, Millar JG, Soriano-Agaton F, Hanks LM, Robertson HM. Sequencing and characterizing odorant receptors of the cerambycid beetle Megacyllene caryae. Insect Biochemistry and Molecular Biology. 2012; 42:499-505. [PubMed: 22504490]

[26]. Xu PX, Choo YM, Pelletier J, Sujimoto FR, Hughes DT, Zhu F, Atungulu E, Cornel AJ, Luetje $\mathrm{CW}$, Leal WS. Silent, generic and plant kairomone sensitive odorant receptors from the Southern house mosquito. Journal of Insect Physiology. 2013; 59:961-966. [PubMed: 23876610]

[27]. Chen SS, Luetje CW. Identification of New Agonists and Antagonists of the Insect Odorant Receptor Co-Receptor Subunit. Plos One. 2012; 7

[28]. Nichols AS, Chen SS, Luetje CW. Subunit Contributions to Insect Olfactory Receptor Function: Channel Block and Odorant Recognition. Chemical Senses. 2011; 36:781-790. [PubMed: 21677030]

[29]. Pask GM, Jones PL, Ruetzler M, Rinker DC, Zwiebel LJ. Heteromeric Anopheline Odorant Receptors Exhibit Distinct Channel Properties. Plos One. 2011; 6

[30]. Nakagawa T, Pellegrino M, Sato K, Vosshall LB, Touhara K. Amino Acid Residues Contributing to Function of the Heteromeric Insect Olfactory Receptor Complex. Plos One. 2012; 7

[31]. Bobkov YV, Ache BW. Block by amiloride derivatives of odor-evoked discharge in lobster olfactory receptor neurons through action on a presumptive TRP channel. Chemical Senses. 2007; 32:149-159. [PubMed: 17098814]

[32]. Schwarzer A, Schauf H, Bauer PJ. Binding of the cGMP-gated channel to the Na/Ca-K exchanger in rod photoreceptors. Journal of Biological Chemistry. 2000; 275:13448-13454. [PubMed: 10788457]

[33]. Poetsch A, Molday LL, Molday RS. The cGMP-gated channel and related glutamic acid-rich proteins interact with peripherin-2 at the rim region of rod photoreceptor disc membranes. Journal of Biological Chemistry. 2001; 276:48009-48016. [PubMed: 11641407]

[34]. Kang K, Bauer PJ, Kinjo TG, Szerencsei RT, Bonigk W, Winkfein RJ, Schnetkamp PPM. Assembly of retinal rod or cone $\mathrm{Na}^{+} / \mathrm{Ca}^{2+}-\mathrm{K}^{+}$exchanger oligomers with cGMP-gated channel subunits as probed with heterologously expressed CDNAs. Biochemistry. 2003; 42:4593-4600. [PubMed: 12693957] 
[35]. Rosker C, Graziani A, Lukas M, Eder P, Zhu MX, Romanin C, Groschner K. $\mathrm{Ca}^{2+}$ signaling by TRPC3 involves $\mathrm{Na}+$ entry and local coupling to the $\mathrm{Na}^{+} / \mathrm{Ca}^{2+}$ exchanger. Journal of Biological Chemistry. 2004; 279:13696-13704. [PubMed: 14736881]

[36]. Eder P, Probst D, Rosker C, Poteser M, Wolinski H, Kohwein S, Romanin C, Groschner K. Phospholipase C-dependent control of cardiac calcium homeostasis involves a TRPC3-NCX1 signaling complex. Cardiovascular Research. 2007; 73:111-119. [PubMed: 17129578]

[37]. Louhivuori LM, Jansson L, Nordstrom T, Bart G, Nasman J, Akerman KE. Selective interference with TRPC3/6 channels disrupts OX1 receptor signalling via NCX and reveals a distinct calcium influx pathway. Cell Calcium. 2010; 48:114-123. [PubMed: 20728215] 


\section{Highlights}

-Na/Ca exchange inhibitor, KB-R7943, blocks recombinant mosquito olfactory receptors.

-KB-R7943 blocks both the odorant-gated current and the odorant-evoked calcium signal.

-Both heteromeric and homomeric OR complexes were susceptible to KB-R7943.

-KB-R7943 represents a valuable tool to investigate the functional properties of arthropod ORs. 


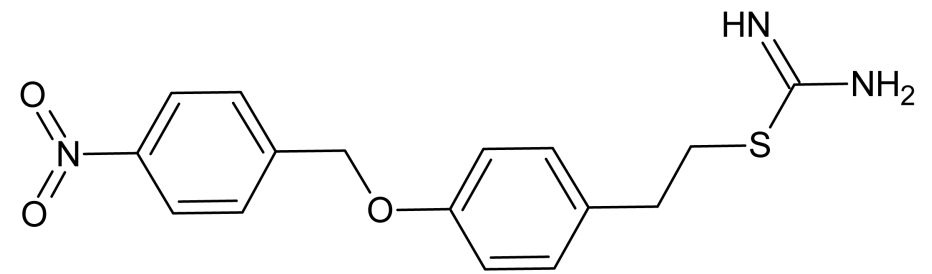

Figure.1.

Chemical structure of KB-R7943. 

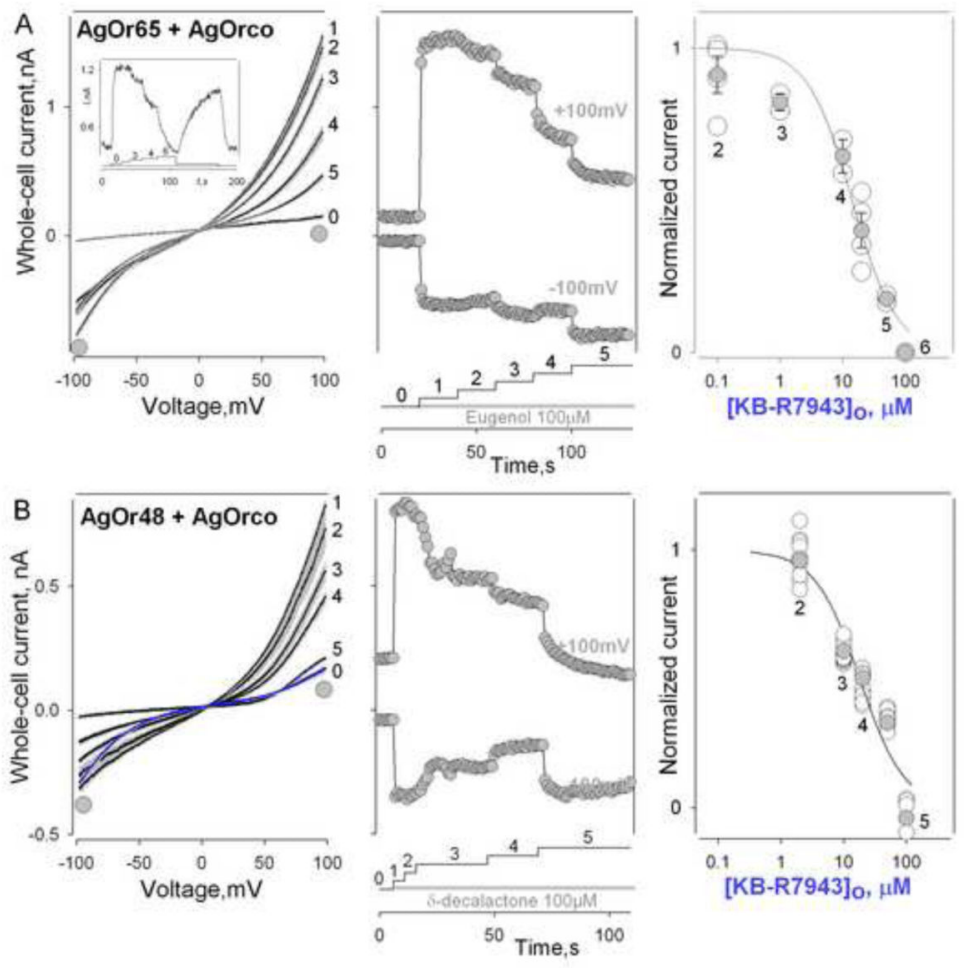

Figure.2.

Effects of KB-R7943 on odorant evoked AgOr mediated currents. KB-R7943 suppresses eugenol $(100 \mu \mathrm{M})$ or $\delta$-decalactone $(100 \mu \mathrm{M})$ activated currents mediated by heteromeric AgOr65/AgOrco (A) or AgOr48/AgOrco (B) complexes heterologously expressed in HEK293T cells. Lefts panels - Series of current voltage characteristics obtained in control condition and in the presence of different [KB-R7943] (curve index - $\mu \mathrm{M}$ ): 1-0, 2-0.1, 3-1, 4-10, 5-50, 6-100. Current voltage dependences were obtained using a $15 \mathrm{~ms}$ duration voltage pulse to $-100 \mathrm{mV}$ followed by a $150 \mathrm{~ms}$ linear voltage change (ramp) to $100 \mathrm{mV}$. Only averaged traces \pm respective SD ranges (grey color) are shown. Leak current subtraction and/or series resistance compensation were not applied. Holding potential was $-50 \mathrm{mV}$. Time between sweep starts was 1s. Middle panels - time course of the KB-R7943 effects. The current values were obtained from current-voltage curves (left panels, respective regions marked by symbols). Inset (A, left) shows that the KB-R7943 effects were at least partially reversible. Gap free current recording was obtained from the same cell. Holding potential was $50 \mathrm{mV}$. Data in Left and Middle panels were obtained from the same cells and have the same current scales. Diagrams at the bottom of the panels depict time course of different [KB-R7943] application. Note, effects of the drug are pronouncedly voltage dependent especially at high concentrations. Right panels - concentration dependencies of KB-R7943. Data were obtained at $100 \mathrm{mV}$. Normalized current mean values (grey circles) were fitted by a modification of the Hill equation with following parameters: for AgOr65/

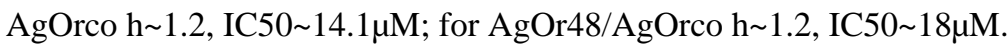



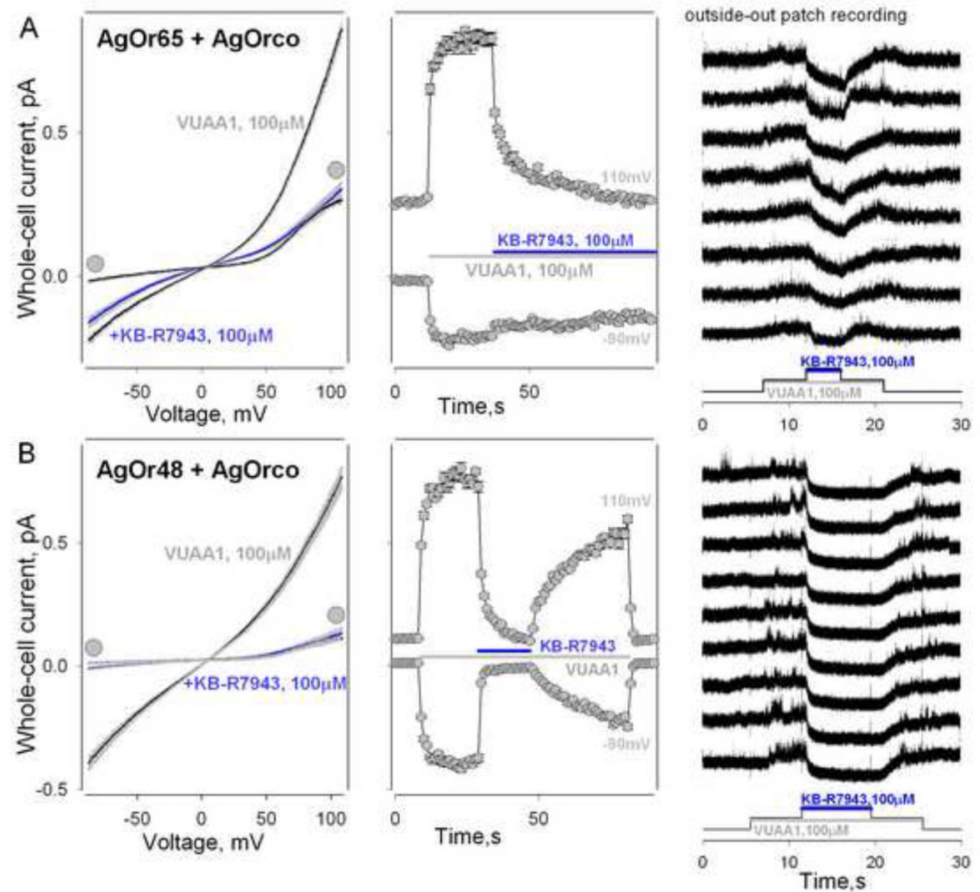

Figure.3.

Effects of KB-R7943 on VUAA1 evoked AgOr mediated currents. KB-R7943 suppresses VUAA1 activated currents mediated by heteromeric AgOr65/AgOrco (A) or AgOr48/ AgOrco (B) complexes. Lefts panels - Series of current-voltage characteristics obtained under control conditions and in the presence of KB-R7943 100 $\mu \mathrm{M}$. Current-voltage dependences were obtained using a $15 \mathrm{~ms}$ duration voltage pulse to $-90 \mathrm{mV}$ followed by a $150 \mathrm{~ms}$ linear voltage change (ramp) to $110 \mathrm{mV}$. Only averaged traces \pm respective SD ranges (grey color) are shown. Leak current subtraction and/or series resistance compensation were not applied. Holding potential was $-40 \mathrm{mV}$. Time between sweep starts was $1 \mathrm{~s}$. Middle panels - time course of the KB-R7943 effects. The current values were obtained from current-voltage curves (left panels, respective regions marked by symbols). Data in Left and Middle panels were obtained from the same cells and have the same current scales. Bars in the panels depict time course of VUAA1 and KB-R7943 application. Note, voltage dependence of drug effects is not pronounced in case of AgOr48/AgOrco. Right panels examples of outside-out patch recordings. AgOr65/AgOrco and AgOr48/AgOrco complexes were activated by the nonspecific agonist VUAA1 followed by reversible inhibition by

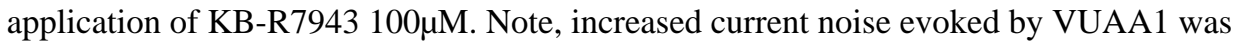
interpreted as an increase in channel activity. Unitary currents are not distinguishable likely due to flickery gating and low single channel conductance. 

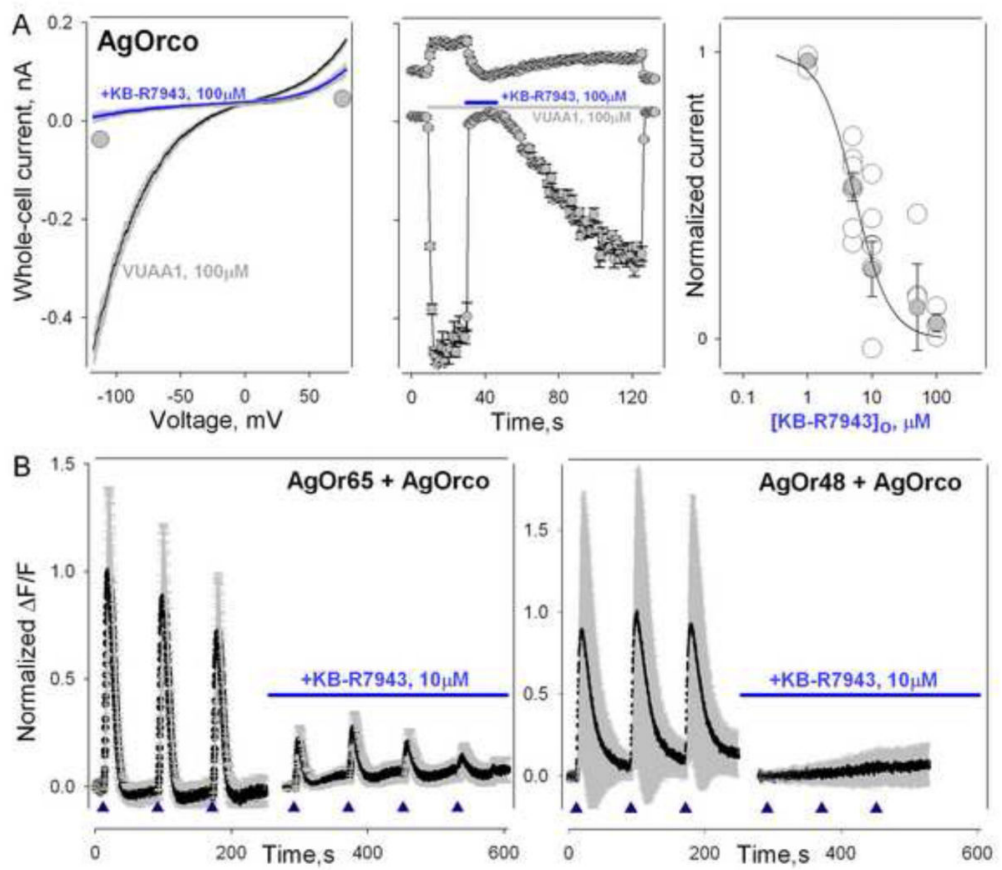

Figure.4.

Effects of KB-R7943 on VUAA1 evoked AgOrco mediated currents.

A - KB-R7943 suppresses VUAA1 activated currents mediated by homomeric AgOrco complexes. Lefts panel - Current-voltage characteristics obtained under control conditions

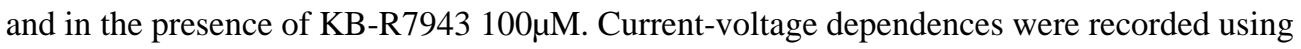
a $15 \mathrm{~ms}$ duration voltage pulse to $-120 \mathrm{mV}$ followed by a $150 \mathrm{~ms}$ linear voltage change (ramp) to $80 \mathrm{mV}$. Only averaged traces \pm respective SD ranges (grey color) are shown. Holding potential was $-70 \mathrm{mV}$. Time between sweep starts was 1s. Middle panel - time course of the KB-R7943 effects. The current values were obtained from current-voltage curves (left panels, respective regions marked by symbols). Data in Left and Middle panel were obtained from the same cell and have the same current scales. Right panel concentration dependencies of KB-R7943. Data were obtained at $80 \mathrm{mV}$. Normalized current mean values (grey circles) were fitted by a modification of the Hill equation with following parameters: $\mathrm{h} \sim 1.6$, IC50 5.4 $\mu \mathrm{M}$. Bars in the panels depict time course of VUAA1 and KBR7943 application.

B - KB-R7943 blocks the stimulus evoked calcium signal in HEK cells expressing either AgOr65/AgOrco (left) or AgOr48/AgOrco (right) complexes. AgOr65/AgOrco expressing cells were stimulated with 50 $\mathrm{M}$ VUAA1 while AgOr48/AgOrco cells were stimulated with $10 \mu \mathrm{M} \delta$-decalactone. AgOr48/AgOrco expressing cells were incubated in the solution containing $2 \mathrm{mM} \mathrm{Ca}^{2+}, 0 \mathrm{Mg}^{2+}$. Triangles and bars in the panels depict the time course of the stimulus (5s pulse duration was used in all cases) and KB-R7943 application. 